\title{
Application of Honey Powder in Bread and its Effect on Bread Characteristics
} Subramaniam Sathivel ${ }^{1,3 *}$, Ahalya Kosal Ram ${ }^{1}$, Luis Espinoza ${ }^{1}$, Joan King ${ }^{1}$, Rafael Cueto ${ }^{2}$ and Kevin Mis Solval ${ }^{3}$

${ }^{1}$ Department of Food Science, Louisiana State University Agricultural Center, Baton Rouge, LA, 70803, USA ${ }^{2}$ Department of Chemistry, Louisiana State University, Baton Rouge, LA, 70803, USA

${ }^{3}$ Department of Biological and Agricultural Engineering, Louisiana State University, Baton Rouge, LA, 70803, USA

\begin{abstract}
Spray dried honey powder could serve as an alternative to sucrose in the bread making process. The objectives of this study were to produce a honey powder containing retrograded starch and use it as an alternative to sucrose in bread formulations. The honey powder was produced by spray drying honey using retrograded starch as a drying agent. Three bread formulations were prepared with (1) $100 \%$ liquid honey (HNY), (2) $50 \%$ substitution of Sugar with Honey Powder (SHP) and (3) 100\% Honey Powder (HP). A bread formulation prepared with only sucrose was used as a control (S). Breads produced from all four formulations were analyzed for loaf volume, weight loss, density, specific volume, moisture content, texture, and freezable water. Triplicate experiments were conducted and data were statistically analyzed at $\alpha=0.05$. Among the bread samples HP showed highest loaf volume $(\mathrm{mL})$ at $1462 \pm 45$ while SHP, HNY and control showed decreasing loaf volumes at $1303 \pm 199,1155 \pm 91$ and $1100 \pm 66$, respectively. All bread samples showed an increase in firmness and HP had a lower rate of staling than the other bread samples during storage. Control bread samples contained more freezable water ( $\mathrm{g} / \mathrm{g}$ solid) at $0.21 \pm 0.003$ than HNY, SHP, and HP which had $0.20 \pm 0.003,0.19 \pm 0.01$ and $0.13 \pm 0.01$, respectively. The study demonstrated that spray dried honey powder with retrograded starch could be used as a substitute for sucrose in baking bread.
\end{abstract}

Keywords: Honey powder; Bread; Texture profile analysis; DSC

\section{Introduction}

Bread is a globally consumed baked product and is a central constituent of many well balanced diets because of its rich starch and complex carbohydrate content [1,2]. According to Mondal and Datta [3], the baking industry has been dynamically changing in the past 150 years in an attempt to optimize the technology so as to cope with various issues that stem from various reasons such as socioeconomics, market competition, changing consumer preferences, needs and attitudes, and changes in the production and quality of the basic ingredients [2]. Sucrose in bread serves as substrate to yeasts primarily for fermentation purposes and contributes to the calorie content of the product with no added nutritional benefits. Diets high in refined carbohydrates such as sucrose are considered one of the major reasons for the rise of obesity in human populations which in turn causes alterations in metabolic activities and lifestyle disorders [4].

Honey could serve as an alternative to sucrose in the bread making process. Honey contains fructose which is more hygroscopic than sucrose and thus bread baked with honey is expected to be moister [5]. However adding honey or honey powder may affect the quality of bread. The primary two attributes that consumers look for to determine quality of bread are its appearance and physical texture [6]. However after baking, the freshness of bread begins to deteriorate rapidly due to various physical and chemical reactions which all together are called staling $[7,8]$.

Staling in bread is of major concern rather than spoilage due to micro-organisms or endogenous enzyme activity [7]. It is estimated that in a market where 20 billion pounds of bread are produced annually at least 600 million (3\%) is lost due to staling problems [9]. Though plenty of literature has been published regarding staling, the process itself remains complex and is not fully understood [10]. Crumb firming is the most important parameter that is linked by consumers to staling [9]. Staling is attributed to many reasons with the prominent ones being starch retro gradation, mainly that of amylopectin [11], interactions between starch and gluten proteins [12], and the loss and redistribution of water [7].

Honey is known to be high in sugars such as fructose and glucose (80-90\%) which also improve browning due to Maillard reactions and also retains moisture when used in baked products [13]. Honey powder produced using retrograded starch could have more health benefits than honey alone due to the presence of the starch. Retrograded starch comprises retrograded amylose whose prolonged intake improves fasting triglyceride and cholesterol levels as opposed to a parallel amylopectin-rich diet [14]. Since retrograded starch is composed mainly of amylose its melting temperature would correspond to that of high molecular weight crystalline amylose which is around $150^{\circ} \mathrm{C}$ [15]. This is the reason retrograded starch is an extremely heat stable pre-biotic starch that can be used in baked or high temperature cooked foods. Honey powder is also more easy to handle and can be uniformly dispersed in a product in comparison to liquid honey. The bread produced using honey or honey powder in this study is expected to have qualities similar to those breads baked using sucrose.

The objectives of this study were to use honey or honey powder containing retrograded starch as an alternative to sucrose in bread formulations and to characterize the bread and study textural changes during a storage period of 12 days.

*Corresponding author: Subramaniam Sathivel, Department of Food Science and Department of Biological and Agricultural Engineering, Louisiana State University Agricultural Center, Baton Rouge, LA 70803-4300, USA, Tel: (225) 578 0614, E mail: ssathivel@agcenter.Isu.edu

Received August 12, 2013; Accepted October 27, 2013; Published November 15,2013

Citation: Sathivel S, Ram AK, Espinoza L, King J, Cuetov R, et al. (2013) Application of Honey Powder in Bread and its Effect on Bread Characteristics. Food Process Technol 4: 279. doi:10.4172/2157-7110.1000279

Copyright: @ 2013 Sathivel S, et al. This is an open-access article distributed unde the terms of the Creative Commons Attribution License, which permits unrestricted use, distribution, and reproduction in any medium, provided the original author and source are credited. 


\section{Materials and Methods}

\section{Honey powder}

Three batches of honey were purchased from local honey producers based in Bossier city, Louisiana. The honey was a multi-floral origin with tallow and willow being among the major sources of pollen. The USDA color designation of the honey was light amber with a value of 79 in the Pfund scale. A solution comprising 20\% honey, 30\% retrograded corn starch (Nutriose FM-06, National Starch Food Innovation, NJ, USA), and $50 \%$ water (by weight) was prepared. The proportions were determined based on preliminary studies. The solution was prepared by mixing continuously using a magnetic stirrer until the honey dissolved completely in the solution. The solution was placed in ice bath and then sonicated using a laboratory scale ultrasonic processor (Model Model CPX 500, Cole-Parmer Inc., Vernon Hills, IL, USA) for 5 minutes at $80 \%$ amplitude (pulse on 2 and pulse off 1 ). Sonication was done to ensure that the retrograded corn starch was well dispersed in the honey solution. The honey solution was spray dried into dry powder using the FT80 tall form spray dryer (Armfiled Limited, Ringwood, Hampshire, England). The honey solution was pumped at a flow rate of $9 \mathrm{~mL} / \mathrm{min}$ and spray dried at $200^{\circ} \mathrm{C}$.

\section{Bread formulation}

The bread was prepared using the Straight dough method for white pan bread followed by American Institute of Baking (AIB). The basic bread formulation per $100 \mathrm{~g}$ of flour was $62 \mathrm{~g}$ water, $3 \mathrm{~g}$ margarine, $7 \mathrm{~g}$ granulated sugar, $2 \mathrm{~g}$ salt and $2 \mathrm{~g}$ Fleishmann freeze dried active yeast. The four formulations for the bread are illustrated in Table 1.

A bread formulation prepared with only sugar (S) was used as a control. Three bread formulations were prepared with (1) 100\% liquid honey (HNY), (2) 50\% substitution of Sugar with Honey Powder (SHP) and (3) $100 \%$ honey powder (HP).

\section{Characterization of flour mixture using Rapid Visco Analyzer (RVA)}

The RVA parameters - peak viscosity, minimum viscosity and final viscosity were determined using a RVA 4 (Newport Scientific, Australia) and RVA data were analyzed using the software Thermo Cline for Windows, Version 3.1. Four formulations as shown in Table 1 without salt, yeast, margarine and water were prepared. A $3.5 \mathrm{~g}$ of sample was weighed and mixed with $25 \mathrm{~mL}$ of water. Each flour mixture with water was held at $50^{\circ} \mathrm{C}$ for $1 \mathrm{~min}$ and then heated to $95^{\circ} \mathrm{C}$ at the rate of $12.2^{\circ} \mathrm{C} / \mathrm{min}$. The heated suspension was then held at $95^{\circ} \mathrm{C}$ for $2.5 \mathrm{~min}$. The cooling cycle then began at the rate of $11.8^{\circ} \mathrm{C} / \mathrm{min}$ till the temperature of $50^{\circ} \mathrm{C}$ was attained after which it was held at the same temperature for $2 \mathrm{~min}$. The values of peak viscosity, minimum viscosity

\begin{tabular}{|c|c|c|c|c|}
\hline & $\begin{array}{c}\text { Control } \\
\text { (with } \\
\text { sucrose) (S) }\end{array}$ & $\begin{array}{c}\text { Substitution } \\
\text { with liquid } \\
\text { honey (HNY) }\end{array}$ & $\begin{array}{c}\text { Substitution } \\
\text { with } \mathbf{5 0 \%} \text { honey } \\
\text { powder (SHP) }\end{array}$ & $\begin{array}{c}\text { Substitution } \\
\text { with } \mathbf{1 0 0 \%} \text { honey } \\
\text { powder (HP) }\end{array}$ \\
\hline Flour & $100 \mathrm{~g}$ & $100 \mathrm{~g}$ & $100 \mathrm{~g}$ & $100 \mathrm{~g}$ \\
\hline Yeast & $2 \mathrm{~g}$ & $2 \mathrm{~g}$ & $2 \mathrm{~g}$ & $2 \mathrm{~g}$ \\
\hline Sucrose & $7 \mathrm{~g}$ & - & $3.5 \mathrm{~g}$ & - \\
\hline Honey & - & $10.6 \mathrm{~g}$ & - & - \\
\hline $\begin{array}{c}\text { Honey } \\
\text { powder }\end{array}$ & - & - & $14 \mathrm{~g}$ & $28 \mathrm{~g}$ \\
\hline Salt & $2 \mathrm{~g}$ & $2 \mathrm{~g}$ & $2 \mathrm{~g}$ & $2 \mathrm{~g}$ \\
\hline Margarine & $3 \mathrm{~g}$ & $3 \mathrm{~g}$ & $3 \mathrm{~g}$ & $3 \mathrm{~g}$ \\
\hline Water & $62 \mathrm{~g}$ & $62 \mathrm{~g}$ & $62 \mathrm{~g}$ & $62 \mathrm{~g}$ \\
\hline
\end{tabular}

Table 1: Bread Formulations. and final viscosity were obtained from the graph generated and these values were used to compute the breakdown and total setback values.

Breakdown $=$ Peak viscosity - Minimum viscosity

Total Set Back (TSB) $=$ Final viscosity - Minimum viscosity

\section{Loaf volume, Specific volume, Density and \%Weight loss}

Loaf volume of bread was determined an hour after baking on day 0 by the bean displacement method [16]. Beans were poured so as to cover the bottom of a container of known volume. The bread loaf was then placed and the remainders of the bean seeds were poured into the container. The beans were leveled on the surface of the container using a spatula. The beans that were not required to fill the container were measured in a graduated cylinder and represented the volume of the loaf. The results were expressed as means of triplicate values along with standard deviation. Specific volume was calculated as the ration of the loaf volume to the loaf weight determined an hour after baking according to the method of Penfield and Campbell [17].

$$
\text { Specific Volumen }\left(\mathrm{cm}^{3} / \mathrm{g}\right)=\frac{\text { Loaf Volume of bread }}{\text { Weight of bread }}
$$

Density was calculated as the ratio of the loaf weight to the loaf volume [18].

Density $\left(\mathrm{g} / \mathrm{cm}^{3}\right)=\frac{\text { Weight of bread }}{\text { Loaf Volume of bread }}$

Weight of the dough and the bread baked were measured and the \% weight loss was calculated as follows

$$
\% \text { Weight Loss }=\frac{\text { Weight of dough }- \text { Weight of baked bread }}{\text { Weight of dough }} \times 100
$$

\section{Crumb and crust color and moisture content of bread during storage}

Bread samples were stored for 12 days at $20^{\circ} \mathrm{C}$ in a temperature controlled incubator. Analysis was conducted on day 0, 1, 3, 6, 9 and 12. Color values for crust and crumb were measured in triplicate at 3 different locations on the same loaf using the HunterLab Labscan XE colorimeter (Labscan XE, Hunter Associates laboratory Inc., Reston, Virginia, USA) fitted with a pulsed xenon lamp. The results were reported as $L^{\star}$ (lightness), a (redness or greenness), and $b^{\star}$ (yellowness or blueness). The measurements were made in triplicate and the means and standard deviations were reported.

Moisture for the crust and crumb was determined by AOAC $969.38 \mathrm{~b}$ method [19], using a forced air convection oven. Three grams of crust and crumb each from 3 different locations on the bread were placed in an oven at $105^{\circ} \mathrm{C}$ for $24 \mathrm{hrs}$. Triplicate measurements were done and values were reported as means along with standard deviations.

\section{Texture profile analysis of bread}

Texture was analyzed using a texture analyzer (TA-XT plus) with a $51 \mathrm{~mm}$ diameter cylindrical probe at test speed of $10 \mathrm{~mm} / \mathrm{s}$ and a $5 \mathrm{~kg}$ load. Bread slices used for testing were cut from the center of the loaf and were $25 \mathrm{~mm}$ thick. Firmness, cohesiveness, springiness values were determined. Chewiness was calculated as follows:

\section{Chewiness $=$ Firmness ${ }^{*}$ Cohesiveness ${ }^{*}$ Springiness}

Triplicate measurements were done and results were expressed as means along with standard deviation. 


\section{Condition for ageing tests and model used to describe staling}

Ageing tests were carried out at $20^{\circ} \mathrm{C}$ for 12 days according to LeBail [20]. The texture analysis was conducted on day $0,1,3,6,9$ and 12. First order kinetic model was used to model the crumb hardening based on the following equation

$$
E(t)=E_{\infty}+\left(E_{0}-E_{\infty}\right) e^{\left(-\frac{t}{\tau}\right)}
$$

Where $E_{0}$ and $E_{\infty}$ represent the Young's modulus at initial time and final storage $($ time $=\infty)$ respectively. The characteristic time constant, $\tau$ was used to characterize and compare the phenomenon of crumb hardening.

The evolution of the crumb hardening was studied by calculating the logarithm of the crumb hardening at the end of storage ( ) when it was not changing (at day 12) and the crumb hardening at a given time during storage period. Therefore, the following equation was obtained:

$$
\operatorname{In}\left(E_{\infty}-E_{t}\right)=\operatorname{In}\left(E_{\infty}-E_{0}\right)-\frac{t}{\tau}
$$

The characteristic time constant, $\tau$ was obtained from the slope of the linear regression of the logarithm of the crumb hardening difference between final value (at day 12) and current value as a function of time. The slope of the linear regression plots is equal to $-1 / \tau$, where $\tau$ has units of time (days).

\section{Differential Scanning Calorimetry (DSC)}

A $10 \mathrm{mg}$ of the core of the bread samples was placed in the hermetically sealed aluminum pans and analyzed using the DSC (TA Instruments, New Castle, DE USA). The samples was first cooled from $25^{\circ} \mathrm{C}$ to $-50^{\circ} \mathrm{C}$ and then slowly heated at a ramp of $2^{\circ} \mathrm{C} / \mathrm{min}$ from $-50^{\circ} \mathrm{C}$ to $100^{\circ} \mathrm{C}$. Condensation in the measurement cell was minimized using dry nitrogen gas flow. The onset $\left(\mathrm{T}_{0}\right)$, peak $\left(\mathrm{T}_{\mathrm{p}}\right)$ and conclusion $\left(\mathrm{T}_{\mathrm{e}}\right)$ temperature was obtained. The amount of freezable water was determined from the relationship between transition enthalpy of ice melting and latent heat of ice melting (334 J/g) [10]. The measurements were carried out in duplicate.

\section{Statistical analysis}

The statistical significance of observed differences among formulation means was evaluated by analysis of variance (ANOVA) (SAS, Version 9.2, SAS Institute Inc., Cary, NC., USA) followed by the post-hoc Turkey's studentized range test (SAS 2002).

\section{Results and Discussion}

\section{RVA data for the flour mixtures}

The peak viscosity values (Table 2) of all of the flour mixture samples were lower than the peak viscosity value of the flour alone. This held true for minimum viscosity, final viscosity, and breakdown and TSB values. This is attributed to the fact that any added ingredient to a flour base always depreciates its gluten forming characteristics due to the absence of proteins in starch which are required for binding especially in the case of SHP and HP flour samples due to the presence of added resistant starch. Fu [21] studied specifically the impact of resistant starch on the physical properties of wheat flour and reported that increasing levels of resistant starch in a resistant starch-wheat flour mixture (up to $20 \%$ ) showed a marked decrease in peak viscosity, breakdown and Total Setback (TSB) values. However they did not affect the pasting temperature or peak time which was also observed in this study.

The breakdown in viscosity is associated with the holding period $\left(95^{\circ} \mathrm{C}\right)$ where the sample is subjected to mechanical stress at a high temperature which results in the breakdown of starch granules with amylose leaching and realignment. The capacity of starch to withstand high temperatures and mechanical stress is an important factor in many processes. High values of breakdown viscosity correspond to high peak viscosities and this correlates to the degree of swelling of the starch granules. The high degree of swelling in turn causes the starch to reach its maximum viscosity very fast while causing breakdown to also occur rapidly due to weak intermolecular forces thus causing them to be sensitive to high temperatures and mechanical stress [22,23]. Therefore it can be concluded that starch granules broke down very easily in descending order of the control, HNY, SHP and HP thereby making the HP sample more resistant to high temperatures. It is also an indication of the denser crystalline structure of HP as compared to the other samples [21].

Total setback, on the other hand, represents the period of cooling which indicates the value obtained due to rearrangement of excreted amylose molecules from starch granules after swelling. This is related to retro gradation with a higher setback value relating to a higher degree of retro gradation [21]. Thus among the samples since HP significantly showed lesser TSB values it indicates that degree of retro gradation is the lowest in this sample thereby implicating that bread made from this formulation would be the softest. This was followed in ascending order

\begin{tabular}{|c|c|c|c|c|c|}
\hline Samples & Peak viscosity $\left(\times 10^{-3} \mathrm{~Pa} \mathrm{~s}\right)$ & $\begin{array}{c}\text { Minimum viscosity } \\
\left(\times 10^{-3} \mathrm{~Pa} \mathrm{~s}\right)\end{array}$ & Final viscosity $\left(\mathrm{x} 10^{-3} \mathrm{~Pa} \mathrm{~s}\right)$ & Breakdown $\left(\times 10^{-3} \mathrm{~Pa} \mathrm{~s}\right)$ & $\begin{array}{c}\text { TSB } \\
\left(\times 10^{-3} \mathrm{~Pa} \mathrm{~s}\right)\end{array}$ \\
\hline Flour & $995 \pm 22.27^{\mathrm{A}}$ & $183 \pm 18^{A}$ & $528.67 \pm 15.95^{A}$ & $812 \pm 5.29^{A}$ & $345.67 \pm 13.50^{A}$ \\
\hline $\mathbf{s}$ & $798 \pm 74.84^{\mathrm{B}}$ & $139.33 \pm 13.65^{B}$ & $416 \pm 27.71^{\mathrm{B}}$ & $658.67 \pm 60.91^{\mathrm{B}}$ & $276.67 \pm 14.22^{\mathrm{A}}$ \\
\hline HNY & $712.67 \pm 7.90^{\mathrm{B}}$ & $118.67 \pm 6.51 \mathrm{~B}^{\mathrm{C}}$ & $375 \pm 10^{\mathrm{BC}}$ & $594 \pm 12.50^{\mathrm{B}}$ & $256.33 \pm 3.51 \mathrm{~B}^{\mathrm{C}}$ \\
\hline SHP & $537.67 \pm 13.65^{c}$ & $98.67 \pm 4.51^{c}$ & $322.33 \pm 22.85^{\mathrm{CD}}$ & $439 \pm 9.17^{c}$ & $223.67 \pm 18.77^{\mathrm{C}}$ \\
\hline HP & $394 \pm 15.87^{D}$ & $92.33 \pm 15.31^{\mathrm{C}}$ & $279.67 \pm 22.48^{D}$ & $301.67 \pm 6.03^{D}$ & $187.33 \pm 11.85^{\mathrm{D}}$ \\
\hline
\end{tabular}
of SHP, HNY and finally the control.

*Values are means $\pm S D$ of 3 determinations. ${ }^{A-D}$ means with different letters in each column are significantly different $(P>0.05)$.

\begin{tabular}{|c|c|c|c|c|}
\hline Sample & Loaf volume $(\mathrm{mL})$ & Density $\left(\mathrm{g} / \mathrm{cm}^{3}\right)$ & Specific volume $\left(\mathrm{cm}^{3} / \mathrm{g}\right)$ & $\%$ Weight loss \\
\hline $\mathbf{S}$ & $1100.00 \pm 65.66^{\mathrm{B}}$ & $0.44 \pm 0.06^{\mathrm{A}}$ & $2.29 \pm 0.27^{\mathrm{A}}$ & $9.14 \pm 1.08^{\mathrm{A}}$ \\
\hline HNY & $1155.44 \pm 90.9^{B}$ & $0.42 \pm 0.07^{A}$ & $2.41 \pm 0.35^{A}$ & $11.21 \pm 1.97^{A}$ \\
\hline SHP & $1303.33 \pm 98.52^{\mathrm{AB}}$ & $0.39 \pm 0.09^{A}$ & $2.68 \pm 0.60^{A}$ & $12.16 \pm 2.19^{A}$ \\
\hline HP & $1461.56 \pm 45.05^{A}$ & $0.35 \pm 0.03^{A}$ & $2.86 \pm 0.22^{\mathrm{A}}$ & $12.98 \pm 2.21^{\mathrm{A}}$ \\
\hline
\end{tabular}

Table 2: RVA Analysis for Flour Samples*

*Values are means $\pm S D$ of 3 determinations. ${ }^{A-B}$ means with different letters in each column are significantly different $(P>0.05)$.

Table 3: Loaf Volume, Density, Specific Density and \%Weight Loss of Bread Samples (Day 0)* 


\section{Loaf volume, specific volume and density of breads}

Loaf volume (Table 3 ) was the highest for HP and was significantly higher than the control bread and HNY while SHP was an intermediate to both. However no significant differences in density, specific density or weight loss were observed. Hathron [2] reported that when bread dough was supplemented with sweet potato flour as well as dough enhancers it caused an increase in loaf volume while increasing concentrations of sweet potato flour alone caused a decrease in loaf volume. This was attributed to the presence of the protein sporamin instead of gluten since it is the latter that is required for forming the structural framework in bread. However the retrograded starch does not contain any protein to contribute to gluten formation and hence higher loaf volume could be due to the presence of a variety of sugars for the yeast to work on. The bread samples had loaf volumes that ranged from $1100 \pm 65.66 \mathrm{~mL}$ to $1461.56 \pm 45.05 \mathrm{~mL}$ which is within range of that reported for supplemented breads especially those with replaced flour [24,2].

Specific volume (Table 3) is an important parameter as it is associated with dough inflating ability and oven spring and extremes in its values affect crumb structure [25]. Smaller values of specific density are associated with compact, dense and closed grain structure while larger values indicate open grain airy structures [26]. Density gives an indication of the size and ratio of air cells to solid product while the $\%$ weight loss is associated with the loss of moisture and entrapped $\mathrm{CO}_{2}$ from the dough matrix [2]. Shogren [18] reported density values of $0.29-0.73 \mathrm{~g} / \mathrm{cm} 3$ for whole wheat bread supplemented with varying concentrations of soy flour which is comparable to the bread samples in this study.

\section{Color measurements of bread crumb and crust over 12 days of storage}

The color of bread crust is mostly attributed to Maillard browning and also caramelization due to the presence of sucrose. Though a clear pattern could not be discerned in terms of lightness of crumb it was seen that in all cases the lightness was higher at the end of 12 days as compared to day 0 (Table 4 ). Redness indicated by $a^{*}$ values decreased over time indicating a lightening of the crumb. HP showed lowest $\mathrm{L}^{\star}$ values for the crust which was followed by SHP, HNY and control in ascending order (Table 5). This indicates that HP had a much darker crust as compared to the other samples which could be attributed to the presence of more types of sugars in the honey powder that contributed to more Maillard browning. Mohamed [27] reported similar findings for bread made with banana flour which was high in sugar content. The crust of bread supplemented with $30 \%$ banana flour was much darker as compared to the breads containing $10 \%$ banana flour and no banana flour. Irregularity in patterns over storage may be due to differences in sampling region and lack of uniformity in browning of the crust.

\section{Moisture content bread crust and crumb over 12 days of storage}

Moisture content of food is an indicator of the quality of the product and has a potential impact on the sensory, physical and microbial properties of bread in particular [2]. In terms of crumb moisture it was

\begin{tabular}{|c|c|c|c|c|c|c|c|}
\hline & & Day 0 & Day 1 & Day 3 & Day 6 & Day 9 & Day 12 \\
\hline $\mathbf{S}$ & \multirow{4}{*}{$L^{*}$} & $59.64 \pm 0.02^{\mathrm{c}, \mathrm{c}}$ & $54.57 \pm 0.17^{\mathrm{D}, \mathrm{b}}$ & $59.91 \pm 0.05^{\mathrm{c}, \mathrm{c}}$ & $60.63 \pm 0.08^{\mathrm{E}, \mathrm{b}}$ & $68.15 \pm 0.05^{\mathrm{B}, \mathrm{a}}$ & $72.32 \pm 0.52^{\mathrm{A}, \mathrm{a}}$ \\
\hline HNY & & $65.53 \pm 0.01^{\mathrm{c}, \mathrm{a}}$ & $62.98 \pm 0.06^{\mathrm{E}, \mathrm{a}}$ & $65.16 \pm 0.01^{\mathrm{D}, \mathrm{a}}$ & $57.79 \pm 0.10^{F, d}$ & $67.55 \pm 0.03^{\mathrm{B}, \mathrm{b}}$ & $68.35 \pm 0.02^{A, b}$ \\
\hline SHP & & $56.74 \pm 0.01^{\mathrm{E}, \mathrm{d}}$ & $54.13 \pm 0.02^{\mathrm{F}, \mathrm{c}}$ & $60.28 \pm 0.01^{\mathrm{D}, \mathrm{b}}$ & $58.13 \pm 0.21^{c, c}$ & $65.82 \pm 0.01^{\mathrm{B}, \mathrm{d}}$ & $70.94 \pm 0.06^{\mathrm{A}, \mathrm{ab}}$ \\
\hline HP & & $63.98 \pm 0.04^{\mathrm{c}, \mathrm{b}}$ & $43.30 \pm 0.02^{\mathrm{F}, \mathrm{d}}$ & $49.69 \pm 0.21^{\mathrm{E}, \mathrm{d}}$ & $62.36 \pm 0.01^{\mathrm{D}, \mathrm{a}}$ & $65.64 \pm 0.02^{\mathrm{B}, \mathrm{C}}$ & $71.78 \pm 0.03^{\mathrm{A}, \mathrm{a}}$ \\
\hline $\mathbf{S}$ & \multirow{4}{*}{$a^{*}$} & $1.54 \pm 0.01^{\mathrm{A}, \mathrm{b}}$ & $1.07 \pm 0.01^{\mathrm{B}, \mathrm{c}}$ & $0.67 \pm 0.02^{\mathrm{c}, \mathrm{d}}$ & $0.64 \pm 0.02^{\mathrm{c}, \mathrm{c}}$ & $0.34 \pm 0.01^{\mathrm{D}, \mathrm{d}}$ & $0.30 \pm 0.02^{\mathrm{D}, \mathrm{d}}$ \\
\hline HNY & & $1.24 \pm 0.01^{\mathrm{A}, \mathrm{d}}$ & $1.04 \pm 0.01^{\mathrm{B}, \mathrm{d}}$ & $0.89 \pm 0.01^{\mathrm{c}, \mathrm{c}}$ & $0.73 \pm 0.01^{\mathrm{D}, \mathrm{b}}$ & $0.56 \pm 0.01^{\mathrm{A}, \mathrm{a}}$ & $0.48 \pm 0.01^{F, c}$ \\
\hline SHP & & $1.44 \pm 0.01^{\mathrm{A}, \mathrm{C}}$ & $1.36 \pm 0.01^{\mathrm{B}, \mathrm{b}}$ & $1.34 \pm 0.01^{\mathrm{B}, \mathrm{b}}$ & $0.97 \pm 0.01^{\mathrm{c}, \mathrm{a}}$ & $0.73 \pm 0.01^{\mathrm{D}, \mathrm{b}}$ & $0.69 \pm 0.01^{\mathrm{E}, \mathrm{b}}$ \\
\hline HP & & $1.74 \pm 0.01^{\mathrm{A}, \mathrm{a}}$ & $1.67 \pm 0.01^{\mathrm{B}, \mathrm{a}}$ & $1.43 \pm 0.01^{\mathrm{c}, \mathrm{a}}$ & $0.98 \pm 0.01^{\mathrm{D}, \mathrm{a}}$ & $0.86 \pm 0.01^{\mathrm{E}, \mathrm{a}}$ & $0.81 \pm 0.01^{\mathrm{F}, \mathrm{a}}$ \\
\hline $\mathbf{S}$ & \multirow{4}{*}{$b^{*}$} & $22.58 \pm 0.01^{\mathrm{B}, \mathrm{C}}$ & $24.96 \pm 0.04^{\mathrm{A}, \mathrm{a}}$ & $20.42 \pm 0.03^{\mathrm{E}, \mathrm{d}}$ & $19.64 \pm 0.04^{F, d}$ & $20.88 \pm 0.02^{\mathrm{D}, \mathrm{d}}$ & $21.67 \pm 0.01^{\mathrm{c}, \mathrm{c}}$ \\
\hline HNY & & $22.14 \pm 0.05^{\mathrm{D}, \mathrm{d}}$ & $24.18 \pm 0.01^{c, d}$ & $30.99 \pm 0.01^{\mathrm{A}, \mathrm{a}}$ & $28.12 \pm 0.01^{\mathrm{B}, \mathrm{a}}$ & $21.67 \pm 0.01^{\mathrm{F}, \mathrm{b}}$ & $21.89 \pm 0.01^{\mathrm{E}, \mathrm{b}}$ \\
\hline SHP & & $22.67 \pm 0.02^{\mathrm{B}, \mathrm{b}}$ & $24.38 \pm 0.02^{A, C}$ & $22.50 \pm 0.01^{c, c}$ & $21.18 \pm 0.01^{\mathrm{E}, \mathrm{c}}$ & $21.54 \pm 0.02^{\mathrm{E}, \mathrm{c}}$ & $23.03 \pm 0.01^{\mathrm{D}, \mathrm{b}}$ \\
\hline HP & & $23.10 \pm 0.02^{\mathrm{D}, \mathrm{a}}$ & $24.51 \pm 0.03^{\mathrm{A}, \mathrm{b}}$ & $23.05 \pm 0.02^{\mathrm{D}, \mathrm{b}}$ & $22.88 \pm 0.01^{\mathrm{E}, \mathrm{b}}$ & $23.37 \pm 0.02^{\mathrm{c}, \mathrm{a}}$ & $24.04 \pm 0.01^{\mathrm{B}, \mathrm{a}}$ \\
\hline
\end{tabular}

*Values are means \pm SD of 3 determinations. A-F means with different letters in each row are significantly different. a-d means with different letters in each column are significantly different $(\mathrm{P}>0.05)$.

Table 4: Crumb Color $L^{*}, A^{*}$ and $B^{*}$ Values of Bread during Storage ${ }^{*}$

\begin{tabular}{|c|c|c|c|c|c|c|c|}
\hline Sample & & Day 0 & Day 1 & Day 3 & Day 6 & Day 9 & Day 12 \\
\hline S & \multirow{4}{*}{$L^{*}$} & $72.34 \pm 0.01^{A, a}$ & $55.56 \pm 0.02^{\mathrm{c}, \mathrm{a}}$ & $54.94 \pm 0.01^{\mathrm{D}, \mathrm{a}}$ & $42.89 \pm 0.03^{F, c}$ & $49.58 \pm 0.04^{\mathrm{E}, \mathrm{c}}$ & $60.91 \pm 0.03^{\mathrm{B}, \mathrm{a}}$ \\
\hline HNY & & $59.69 \pm 0.05^{\mathrm{B}, \mathrm{b}}$ & $52.6 \pm 0.09^{\mathrm{D}, \mathrm{b}}$ & $41.03 \pm 0.01^{\mathrm{Fc}}$ & $49.76 \pm 0.2^{\mathrm{E}, \mathrm{b}}$ & $64.21 \pm 0.01^{\mathrm{A}, \mathrm{a}}$ & $54.73 \pm 0.03^{\mathrm{c}, \mathrm{b}}$ \\
\hline SHP & & $47.80 \pm 0.04^{\mathrm{D}, \mathrm{c}}$ & $48.34 \pm 0.01^{\mathrm{c}, \mathrm{c}}$ & $47.59 \pm 0.02^{\mathrm{E}, \mathrm{b}}$ & $53.96 \pm 0.02^{\mathrm{B}, \mathrm{a}}$ & $60.82 \pm 0.01^{\mathrm{A}, \mathrm{b}}$ & $47.86 \pm 0.03^{\mathrm{D}, \mathrm{c}}$ \\
\hline HP & & $43.3 \pm 0.02^{\mathrm{C}, \mathrm{d}}$ & $48.54 \pm 0.02^{A, d}$ & $38.96 \pm 0.02^{E, d}$ & $42.43 \pm 0.15^{\mathrm{D}, \mathrm{c}}$ & $44.91 \pm 0.01^{\mathrm{B}, \mathrm{d}}$ & $37.54 \pm 0.01^{\mathrm{F}, \mathrm{d}}$ \\
\hline $\mathbf{S}$ & \multirow{4}{*}{$a^{*}$} & $10.58 \pm 0.01^{\mathrm{D}, \mathrm{b}}$ & $12.72 \pm 0.02^{\mathrm{B}, \mathrm{C}}$ & $13.08 \pm 0.01^{A, C}$ & $10.86 \pm 0.02^{\mathrm{c}, \mathrm{b}}$ & $9.69 \pm 0.01^{\mathrm{E}, \mathrm{b}}$ & $12.76 \pm 0.01^{\mathrm{B}, \mathrm{C}}$ \\
\hline HNY & & $14.02 \pm 0.01^{\mathrm{A}, \mathrm{a}}$ & $11.91 \pm 0.02^{c, d}$ & $12.35 \pm 0.01^{\mathrm{B}, \mathrm{d}}$ & $7.63 \pm 0.06^{\mathrm{D}, \mathrm{d}}$ & $6.60 \pm 0.01^{\mathrm{F}, \mathrm{d}}$ & $6.67 \pm 0.01^{\mathrm{E}, \mathrm{d}}$ \\
\hline SHP & & $12.13 \pm 0.03^{D, C}$ & $13.33 \pm 0.01^{c, b}$ & $15.46 \pm 0.01^{A, b}$ & $9.52 \pm 0.01^{\mathrm{E}, \mathrm{c}}$ & $9.52 \pm 0.01^{\mathrm{E}, \mathrm{c}}$ & $13.93 \pm 0.01^{\mathrm{B}, \mathrm{b}}$ \\
\hline HP & & $13.71 \pm 0.02^{\mathrm{D}, \mathrm{b}}$ & $14.33 \pm 0.24^{\mathrm{c}, \mathrm{a}}$ & $16.33 \pm 0.01^{\mathrm{A}, \mathrm{a}}$ & $15.06 \pm 0.03^{\mathrm{B}, \mathrm{a}}$ & $13.77 \pm 0.01^{\mathrm{D}, \mathrm{a}}$ & $14.59 \pm 0.01^{\mathrm{c}, \mathrm{a}}$ \\
\hline $\mathbf{S}$ & \multirow{4}{*}{$b^{*}$} & $28.45 \pm 0.01^{A, C}$ & $24.18 \pm 0.01^{c, c}$ & $20.42 \pm 0.03^{E, d}$ & $21.77 \pm 0.03^{\mathrm{D}, \mathrm{d}}$ & $28.23 \pm 0.01^{\mathrm{B}, \mathrm{c}}$ & $24.21 \pm 0.01^{\mathrm{c}, \mathrm{d}}$ \\
\hline HNY & & $28.56 \pm 0.04^{A, b}$ & $23.07 \pm 0.01^{\mathrm{E}, \mathrm{d}}$ & $24.73 \pm 0.01^{\mathrm{D}, \mathrm{b}}$ & $23.06 \pm 0.10^{\mathrm{E}, \mathrm{C}}$ & $26.79 \pm 0.03^{\mathrm{B}, \mathrm{d}}$ & $25.81 \pm 0.03^{c, c}$ \\
\hline SHP & & $28.39 \pm 0.03^{\mathrm{B}, \mathrm{d}}$ & $26.21 \pm 0.01^{\mathrm{D}, \mathrm{b}}$ & $22.66 \pm 0.02^{\mathrm{E}, \mathrm{c}}$ & $28.44 \pm 0.14^{\mathrm{B}, \mathrm{b}}$ & $33.22 \pm 0.01^{\mathrm{A}, \mathrm{a}}$ & $27.84 \pm 0.04^{\mathrm{c}, \mathrm{b}}$ \\
\hline HP & & $28.77 \pm 0.01^{\mathrm{E}, \mathrm{a}}$ & $29.37 \pm 0.01^{\mathrm{B}, \mathrm{a}}$ & $27.82 \pm 0.03^{F, a}$ & $30.41 \pm 0.04^{\mathrm{A}, \mathrm{a}}$ & $29.15 \pm 0.03^{c, b}$ & $28.98 \pm 0.04^{\mathrm{D}, \mathrm{a}}$ \\
\hline
\end{tabular}

*Values are means \pm SD of 3 determinations. A-F means with different letters in each row are significantly different. a-d means with different letters in each column are significantly different $(\mathrm{P}>0.05)$.

Table 5: Crust Color $L^{*}, A^{*}$ and $B^{*}$ Values of Bread during Storage * 
Citation: Sathivel S, Ram AK, Espinoza L, King J, Cuetov R, et al. (2013) Application of Honey Powder in Bread and its Effect on Bread Characteristics. J Food Process Technol 4: 279. doi:10.4172/2157-7110.1000279

Page 5 of 9

\begin{tabular}{|c|c|c|c|c|c|c|}
\hline Sample & Day 0 & Day 1 & Day 3 & Day 6 & Day 9 & Day 12 \\
\hline $\mathbf{S}$ & $41.06 \pm 0.76^{\mathrm{A}, \mathrm{b}}$ & $40.85 \pm 0.99^{A, a}$ & $40.38 \pm 0.98^{\mathrm{A}, \mathrm{a}}$ & $38.71 \pm 0.02^{\mathrm{A}, \mathrm{a}}$ & $39.57 \pm 0.74^{\mathrm{A}, \mathrm{ab}}$ & $38.64 \pm 0.87^{A, a}$ \\
\hline HNY & $42.14 \pm 2.62^{\mathrm{A}, \mathrm{ab}}$ & $41.53 \pm 1.56^{\mathrm{AB}, \mathrm{a}}$ & $38.94 \pm 1.58^{\mathrm{AB}, \mathrm{ab}}$ & $37.35 \pm 1.18^{\mathrm{B}, \mathrm{a}}$ & $40.21 \pm 1.62^{\mathrm{AB}, \mathrm{a}}$ & $38.71 \pm 0.10^{\mathrm{AB}, \mathrm{a}}$ \\
\hline SHP & $39.17 \pm 3.90^{\mathrm{A}, \mathrm{b}}$ & $38.71 \pm 0.01^{\mathrm{AB}, \mathrm{ab}}$ & $36.82 \pm 1.16^{\mathrm{ABC}, \mathrm{bc}}$ & $34.05 \pm 1.24^{\mathrm{ABC}, a}$ & $36.15 \pm 1.16^{\mathrm{BC}, \mathrm{b}}$ & $33.33 \pm 0.96^{\mathrm{c}, \mathrm{b}}$ \\
\hline HP & $50.07 \pm 4.26^{\mathrm{A}, \mathrm{a}}$ & $37.23 \pm 1.6^{\mathrm{B}, \mathrm{b}}$ & $34.74 \pm 0.64^{\mathrm{B}, \mathrm{c}}$ & $34.01 \pm 1.39^{\mathrm{B}, \mathrm{a}}$ & $31.86 \pm 1.70^{\mathrm{B}, \mathrm{C}}$ & $31.11 \pm 1.92^{\mathrm{B}, \mathrm{b}}$ \\
\hline
\end{tabular}

*Values are means $\pm S D$ of 3 determinations. ${ }^{A-D}$ means with different letters in each row are significantly different. ${ }^{a-c}$ means with different letters in each column are significantly different $(\mathrm{P}>0.05)$.

Table 6: Moisture Content (\%) Values of Bread Crumb*

\begin{tabular}{|c|c|c|c|c|c|c|}
\hline Sample & Day 0 & Day 1 & Day 3 & Day 6 & Day 9 & Day 12 \\
\hline $\mathbf{S}$ & $24.71 \pm 1.86^{\mathrm{B}, \mathrm{ab}}$ & $27.96 \pm 1.86^{\mathrm{AB}, \mathrm{ab}}$ & $29.68 \pm 0.56^{\mathrm{A}, \mathrm{a}}$ & $29.75 \pm 0.56^{\mathrm{A}, \mathrm{ab}}$ & $31.11 \pm 1.92^{\mathrm{A}, \mathrm{a}}$ & $31.18 \pm 1.86^{A, a}$ \\
\hline HNY & $27.71 \pm 2.52^{\mathrm{A}, \mathrm{a}}$ & $28.98 \pm 2.29^{\mathrm{A}, \mathrm{a}}$ & $30.75 \pm 1.30^{\mathrm{A}, \mathrm{a}}$ & $32.58 \pm 1.75^{\mathrm{A}, \mathrm{a}}$ & $30.43 \pm 1.65^{\mathrm{A}, \mathrm{a}}$ & $31.54 \pm 2.23^{\mathrm{A}, \mathrm{a}}$ \\
\hline SHP & $21.48 \pm 1.33^{\mathrm{c}, \mathrm{b}}$ & $24.19 \pm 1.40^{\mathrm{AB}, \mathrm{a}}$ & $28.24 \pm 1.37^{\mathrm{AB}, \mathrm{ab}}$ & $29.35 \pm 1.49^{\mathrm{AB}, \mathrm{ab}}$ & $29.67 \pm 0.56^{\mathrm{A}, \mathrm{a}}$ & $30.78 \pm 2.25^{\mathrm{A}, \mathrm{a}}$ \\
\hline HP & $20.21 \pm 1.57^{\mathrm{c}, \mathrm{b}}$ & $22.58 \pm 0.01^{\mathrm{BC}, \mathrm{b}}$ & $24.46 \pm 1.68^{\mathrm{BC}, \mathrm{b}}$ & $25.27 \pm 1.73^{\mathrm{AB}, \mathrm{b}}$ & $26.09 \pm 0.50^{A B, b}$ & $29.64 \pm 0.49^{A, a}$ \\
\hline
\end{tabular}

Values are means $\pm S D$ of 3 determinations. ${ }^{A-D}$ means with different letters in each row are significantly different. ${ }^{a-c}$ means with different letters in each column are significantly different $(P>0.05)$.

Table 7: Moisture Content (\%) Values of Bread Crust.

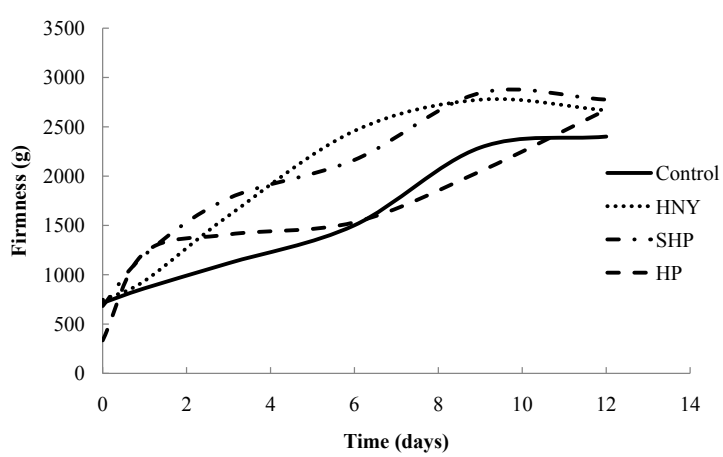

Figure 1: Firmness Changes during 12 Day Storage of Control, HNY, SHP and HP Breads.

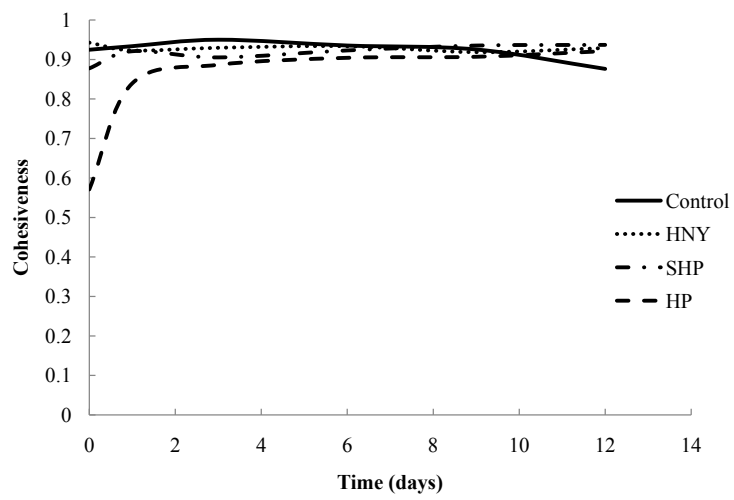

Figure 2: Cohesiveness Changes during 12 Day Storage of Control, HNY, SHP and HP Breads

seen that HP was the highest on day 0 from the other three samples which were comparable to each other (Table 6). Higher moisture content as long as it is in the acceptable range has shown to positively increase the loaf volumes of bread [28]. The four bread samples on all days showed moisture content values that were comparable to those reported in literature [2,11]. All of the breads showed an expected trend of decrease in crumb moisture over the 12 day storage period but the control did not. The decrease in crumb moisture corresponded to an increase in the crust moisture (Table 7) over the 12 days. Altamirano and Rossel [1] reported the same and also contributed any increase in moisture during storage to absorption of water from the atmosphere due to the moisture gradient between crumb and crust. This moisture gradient varied with each bread sample even though storage conditions remained the same. Primo-Martin [29] contributed the loss of crispiness of crust during storage primarily due to its increase in water content since water acts as a plasticizer and starch retro gradation was only secondary as it sets in only 2 days later.

\section{TPA results of control, HNY, SHP and HP}

The extremely high values of firmness, resilience, cohesiveness, 


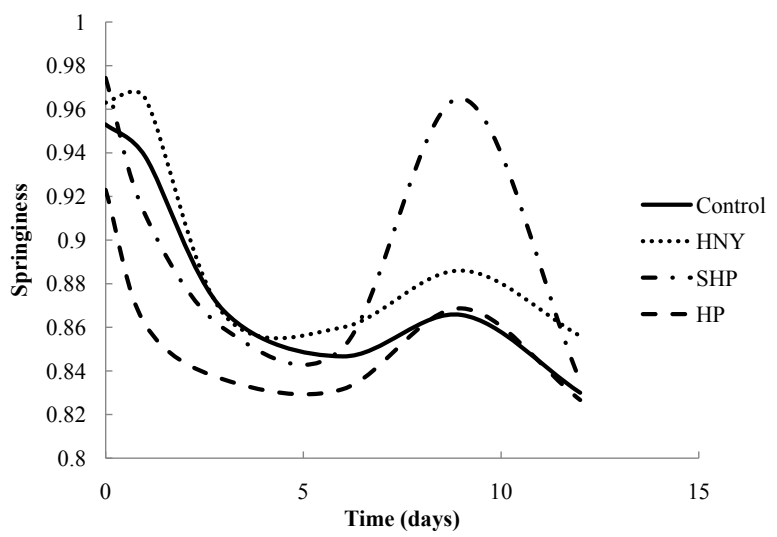

Figure 3: Springiness Changes during 12 Day Storage of Control, HNY, SHP and HP Breads.

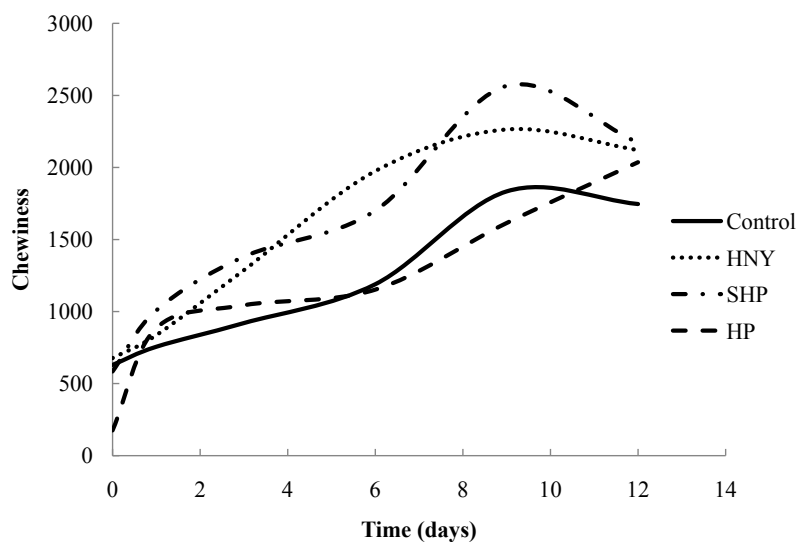

Figure 4: Chewiness Changes during 12 Day Storage of Control, HNY, SHP and HP Breads.

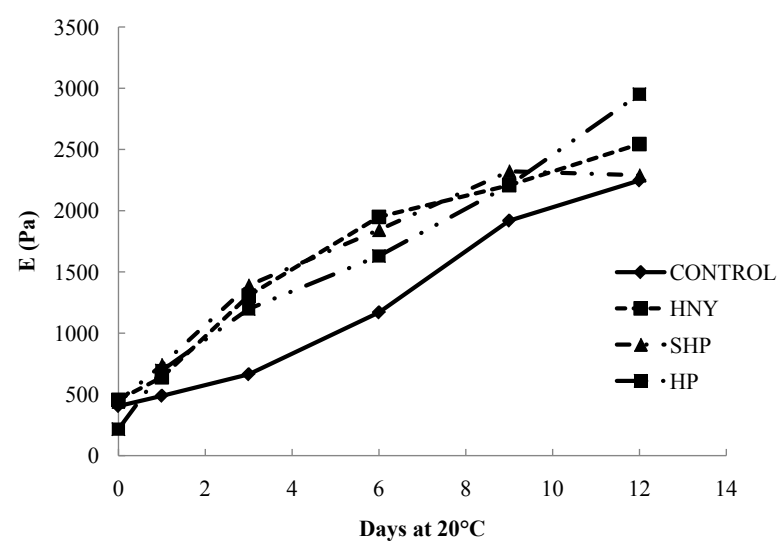

Figure 5: Evolution of Young's Modulus Of Bread Samples During Storage.

\begin{tabular}{|c|c|c|c|}
\hline Samples & $\ln \left(E_{\infty}-E_{t}\right)=\ln \left(E_{\infty}-E_{0}\right)-t / T$ & Time constant & $\mathbf{R}^{2}$ \\
\hline S & $\ln \left(E_{\infty}-E_{t}\right)=7.713-0.1807 t$ & $5.45 \pm 0.95^{A B}$ & 0.86 \\
\hline HNY & $\ln \left(E_{\infty}-E_{t}\right)=7.708-0.2114 t$ & $4.69 \pm 0.51^{A B}$ & 0.99 \\
\hline SHP & $\ln \left(E_{\infty}-E_{t}\right)=7.545-0.2417 t$ & $3.29 \pm 0.70^{B}$ & 0.99 \\
\hline HP & $\ln \left(E_{\infty}-E_{t}\right)=7.899-0.1365 t$ & $7.37 \pm 1.31^{A}$ & 0.98 \\
\hline
\end{tabular}

*Values are means $\pm S D$ of 3 determinations. ${ }^{A-D}$ means with different letters in each row are significantly different. ${ }^{\text {a-d }}$ means with different letters in each column are significantly different $(P>0.05)$.

Table 8: Time Constant Values Of Bread Samples* 
springiness and chewiness as compared to those reported generally in literature is attributed to the fact that the probe size used in this study was $51 \mathrm{~mm}$ in diameter as opposed to the $25 \mathrm{~mm}$ that is generally used. High values similar to the one in this study were reported by Mohamed [27] as the probe used was $35 \mathrm{~mm}$ in diameter.

The four bread samples showed increased firmness (Figure 1) with an increase in days of storage and there was a significant change in the firmness values over the 12 days which is attributed to staling, mainly the phenomenon of amylopectin retro gradation. On day 1 Control, HNY and SHP showed no significant difference in their firmness values and were significantly higher only in comparison to HP. However day 2 saw a marked increase in HP bread which was comparable to SHP but significantly higher than control. On days 3, 6 and 9 however, HP and control did not show any significant difference in values in comparison to each other though they were significantly lower than the HNY and SHP. On day 12 all of the four samples did not show any significant difference in firmness values. The decrease in crumb moisture values correspond to the increase in firmness though the differences in firmness were much more significant that the corresponding moisture content. This is due to the fact that amylose leaches out during baking thus causing retro gradation to occur quickly during cooling leading to crumb firming while the longer storage period is characterized by amylopectin retro gradation as the main ageing factor [30]. Presence of increased sugar levels is attributed to increasing bread firmness as it affected water distribution as well as trapped moisture within the bread structure [27]. However the presence of fibers helps decrease the firmness Mohamed [31] thus explaining why HP showed the least firmness among all four samples. The lack of significant difference on day 12 has been observed even in a study involving addition of banana flour to the bread formulation where after 7 days of storage at $25^{\circ} \mathrm{C}$ the samples differing in the level of banana flour concentration showed no significant difference [27]. The difference in the number of days for firmness to stabilize could be due to the difference in the temperature at which storage study was conducted.

Cohesiveness (Figure 2) for the control bread decreased overall during the storage period though there was no clear trend. However, HNY showed no significant change in cohesiveness during storage while SHP and HP showed an increase in cohesiveness values. On all days HP showed lower values of cohesiveness than the control while HNY and SHP were for most part comparable to the control values. Springiness values (Figure 3 ) for all samples were highest on day 0 and decreased from day 1 onwards though the decrease after day 1 was not significant. However, on each day the springiness of HP and control did not significantly differ from each other and they were lower than those of SHP and HNY which were again not significantly different from each other. Firmness, springiness and cohesiveness are the indicators of bread freshness [32]. Charoenthaikij reported a similar trend of increasing firmness with a decrease in both cohesiveness and springiness values over storage time in wheat flour bread substituted with germinated rice flour. Thus a decreasing cohesiveness value and springiness value adds to the firming of bread. From the above it can be concluded that overall the degree and extent of firmness of control bread and HP was almost the same.

Chewiness is given as the energy required for masticating a solid food (Stable Micro Systems, Texture Exponent Analysis). The four bread samples showed increase in chewiness values (Figure 4) over the 12 days with a significant difference between day 0 and day 12 in all samples. Day 1, 3, 6 and 9 did not show very significant changes in chewiness generally though they were significantly different from the values obtained on day 0 and 12 except for day 1 and 9 for the control and HNY

\section{Study of staling rate during storage}

The Young's modulus (Figure 5) showed a steady increase over the storage period and in case of HNY and SHP almost stabilized at day 9. This is expected though in the other 2 samples there was significant difference between day 9 and 12. Young modulus is supposed to have stabilized after day 8 though it can be safely assumed that day 12 represents time infinity. Stabilization time can vary and in some cases depending on baking conditions has been even 6 days [20]. The time constant (Table 8) obtained from the values of the Young modulus indicate that HP showed the highest value of the same and was significantly different from SHP. However control and HNY showed intermediate results to both the control and HP. The time constant value of HP was almost twice that of SHP and this is an indication of the staling rate of SHP being much faster than that of HP. However that

\begin{tabular}{|c|c|c|c|c|c|c|c|}
\hline & & DAY 0 & DAY 1 & DAY 3 & DAY 6 & DAY 9 & DAY 12 \\
\hline Control & \multirow{4}{*}{$\mathrm{T}_{0}\left({ }^{\circ} \mathrm{C}\right)$} & $-12.64 \pm 1.07^{\mathrm{A}, \mathrm{a}}$ & $-13.17 \pm 0.77^{\mathrm{A}, \mathrm{a}}$ & $-15.21 \pm 0.49^{A B, b c}$ & $-15.24 \pm 1.19^{A B, a}$ & $-15.65 \pm 0.30^{A B, a}$ & $-16.67 \pm 0.52^{\mathrm{B}, \mathrm{ab}}$ \\
\hline HNY & & $-12.95 \pm 0.49^{\mathrm{A}, a b}$ & $-12.02 \pm 0.66^{\mathrm{A}, \mathrm{a}}$ & $-12.28 \pm 0.20^{\mathrm{A}, \mathrm{a}}$ & $-13.43 \pm 1.04^{\mathrm{A}, \mathrm{a}}$ & $-16.78 \pm 2.83^{\mathrm{A}, \mathrm{a}}$ & $-14.91 \pm 0.07^{\mathrm{A}, \mathrm{a}}$ \\
\hline SHP & & $-13.16 \pm 0.34^{\mathrm{A}, \mathrm{ab}}$ & $-14.01 \pm 0.78^{\mathrm{A}, \mathrm{a}}$ & $-13.72 \pm 0.02^{\mathrm{A}, \mathrm{ab}}$ & $-16.99 \pm 1.11^{\mathrm{B}, \mathrm{a}}$ & $-18.16 \pm 0.20^{\mathrm{B}, \mathrm{a}}$ & $-17.04 \pm 0.83^{\mathrm{B}, \mathrm{b}}$ \\
\hline HP & & $-15.29 \pm 0.001^{A, b}$ & $-15.01 \pm 1.70^{\mathrm{A}, \mathrm{a}}$ & $-16.44 \pm 0.71^{\mathrm{A}, \mathrm{C}}$ & $-17.25 \pm 0.37^{A, a}$ & $-17.39 \pm 0.01^{\mathrm{A}, \mathrm{a}}$ & $-17.57 \pm 0.29^{A, b}$ \\
\hline Control & \multirow{4}{*}{$\mathrm{T}_{\mathrm{p}}\left({ }^{\circ} \mathrm{C}\right)$} & $-5.97 \pm 0.45^{\mathrm{A}, \mathrm{a}}$ & $-6.94 \pm 0.40^{\mathrm{A}, \mathrm{a}}$ & $-7.83 \pm 0.75^{\mathrm{A}, \mathrm{ab}}$ & $-7.77 \pm 0.09^{\mathrm{A}, \mathrm{a}}$ & $-8.34 \pm 0.05^{\mathrm{AB}, \mathrm{a}}$ & $-10.25 \pm 1.11^{\mathrm{B}, \mathrm{a}}$ \\
\hline HNY & & $-6.19 \pm 0.11^{\mathrm{A}, \mathrm{a}}$ & $-5.98 \pm 0.26^{\mathrm{A}, \mathrm{a}}$ & $-6.25 \pm 0.40^{\mathrm{A}, \mathrm{a}}$ & $-7.14 \pm 0.77^{\mathrm{A}, \mathrm{a}}$ & $-9.86 \pm 3.69^{\mathrm{A}, \mathrm{a}}$ & $-7.91 \pm 0.18^{\mathrm{A}, \mathrm{a}}$ \\
\hline SHP & & $-6.90 \pm 0.29^{\mathrm{A}, \mathrm{a}}$ & $-6.70 \pm 0.53^{\mathrm{A}, \mathrm{a}}$ & $-6.96 \pm 0.23^{\mathrm{A}, \mathrm{ab}}$ & $-9.52 \pm 1.75^{\mathrm{AB}, \mathrm{a}}$ & $-11.89 \pm 0.39^{\mathrm{B}, \mathrm{a}}$ & $-10.33 \pm 1.51^{\mathrm{AB}, \mathrm{a}}$ \\
\hline HP & & $-8.10 \pm 0.18^{A, b}$ & $-10.06 \pm 2.43^{\mathrm{A}, \mathrm{a}}$ & $-8.76 \pm 0.86^{A, b}$ & $-9.61 \pm 1.03^{\mathrm{A}, \mathrm{a}}$ & $-10.39 \pm 0.19^{\mathrm{A}, \mathrm{a}}$ & $-10.25 \pm 0.50^{\mathrm{A}, \mathrm{a}}$ \\
\hline Control & \multirow{4}{*}{$\mathrm{T}_{\mathrm{e}}\left({ }^{\circ} \mathrm{C}\right)$} & $-2.08 \pm 1.76^{\mathrm{A}, \mathrm{a}}$ & $-4.68 \pm 0.23^{\mathrm{AB}, \mathrm{ab}}$ & $-4.66 \pm 0.21^{\mathrm{AB}, \mathrm{a}}$ & $-4.91 \pm 0.62^{\mathrm{AB}, \mathrm{a}}$ & $-5.12 \pm 0.33^{\mathrm{AB}, \mathrm{a}}$ & $-5.67 \pm 0.02^{\mathrm{B}, \mathrm{a}}$ \\
\hline HNY & & $-3.14 \pm 0.21^{\mathrm{A}, \mathrm{a}}$ & $-2.87 \pm 0.21^{A, a}$ & $-3.21 \pm 0.26^{\mathrm{A}, a}$ & $-4.10 \pm 0.52^{\mathrm{A}, \mathrm{a}}$ & $-5.82 \pm 2.33^{\mathrm{A}, \mathrm{a}}$ & $-5.07 \pm 0.12^{A, a}$ \\
\hline SHP & & $-3.58 \pm 0.42^{\mathrm{A}, \mathrm{a}}$ & $-3.88 \pm 0.39^{\mathrm{A}, \mathrm{ab}}$ & $-3.12 \pm 0.86^{\mathrm{A}, \mathrm{a}}$ & $-5.49 \pm 0.81^{\mathrm{AB}, \mathrm{a}}$ & $-7.26 \pm 0.23^{\mathrm{B}, \mathrm{a}}$ & $-5.83 \pm 1.14^{A B, a}$ \\
\hline HP & & $-5.10 \pm 0.55^{\mathrm{A}, \mathrm{a}}$ & $-5.67 \pm 0.98^{A, b}$ & $-5.17 \pm 0.64^{\mathrm{A}, \mathrm{a}}$ & $-5.53 \pm 0.22^{\mathrm{A}, \mathrm{a}}$ & $-6.26 \pm 0.03^{\mathrm{A}, \mathrm{a}}$ & $-6.73 \pm 0.19^{A, a}$ \\
\hline Control & \multirow{4}{*}{$\mathrm{T}_{\mathrm{g}}\left({ }^{\circ} \mathrm{C}\right)$} & $-12.3 \pm 0.88^{\mathrm{A}, \mathrm{a}}$ & $-12.98 \pm 0.60^{\mathrm{AB}, \mathrm{ab}}$ & $-14.87 \pm 0.28^{\mathrm{ABC}, \mathrm{b}}$ & $-15.26 \pm 1.22^{\mathrm{BC}, \mathrm{ab}}$ & $-15.39 \pm 0.21^{\mathrm{BC}, \mathrm{a}}$ & $-16.48 \pm 0.51^{\mathrm{C}, \mathrm{ab}}$ \\
\hline HNY & & $-12.86 \pm 0.39^{A, a}$ & $-11.8 \pm 0.72^{\mathrm{A}, \mathrm{a}}$ & $-11.97 \pm 0.11^{\mathrm{A}, \mathrm{a}}$ & $-13.28 \pm 0.99^{\mathrm{A}, \mathrm{a}}$ & $-16.55 \pm 2.64^{\mathrm{A}, \mathrm{a}}$ & $-14.86 \pm 0.14^{\mathrm{A}, \mathrm{a}}$ \\
\hline SHP & & $-13.20 \pm 0.45^{\mathrm{A}, \mathrm{a}}$ & $-13.99 \pm 0.95^{\mathrm{AB}, \mathrm{ab}}$ & $-13.78 \pm 0.06^{\mathrm{A}, \mathrm{b}}$ & $-16.73 \pm 1.08^{\mathrm{BC}, \mathrm{ab}}$ & $-18.11 \pm 0.13^{c, a}$ & $-17.05 \pm 0.74^{c, b}$ \\
\hline HP & & $-15.42 \pm 0.04^{A, b}$ & $-17.39 \pm 1.75^{\mathrm{A}, \mathrm{b}}$ & $-16.35 \pm 0.65^{A, C}$ & $-17.40 \pm 0.34^{\mathrm{A}, \mathrm{b}}$ & $-17.71 \pm 0.31^{\mathrm{A}, \mathrm{a}}$ & $-17.63 \pm 0.41^{A, b}$ \\
\hline
\end{tabular}

*Values are means \pm SD of 3 determinations. ${ }^{A-C}$ means with different letters in each row are significantly different. a-c means with different letters in each column are significantly different $(\mathrm{P}>0.05)$.

Table 9: Onset Temperature $\left(T_{0}\right)$, Peak Temperature $\left(T_{p}\right)$, Conclusion Temperature $\left(T_{e}\right)$ And Glass Transition ( $\left.T_{q}\right)$ For Control, HNY, SHP And HP Breads As Obtained From DSC* 


\begin{tabular}{|c|c|c|c|c|c|c|c|}
\hline & & DAY 0 & DAY 1 & DAY 3 & DAY 6 & DAY 9 & DAY 12 \\
\hline Control & \multirow{4}{*}{$\underset{(\mathrm{J} / \mathrm{g})}{\Delta \mathrm{H}}$} & $71.65 \pm 1.04^{\mathrm{A}, \mathrm{a}}$ & $52.12 \pm 0.77^{\mathrm{B}, \mathrm{b}}$ & $46.19 \pm 0.19 \mathrm{c}, \mathrm{b}$ & $43.06 \pm 0.51^{\mathrm{c}, \mathrm{b}}$ & $38.99 \pm 0.45^{\mathrm{D}, \mathrm{a}}$ & $27.81 \pm 1.69^{\mathrm{E}, \mathrm{b}}$ \\
\hline HNY & & $67.66 \pm 1.18^{\mathrm{A}, \mathrm{ab}}$ & $66.44 \pm 1.79^{\mathrm{A}, \mathrm{a}}$ & $56.85 \pm 0.81^{\mathrm{B}, \mathrm{a}}$ & $48.13 \pm 0.62^{\mathrm{c}, \mathrm{a}}$ & $46.23 \pm 1.51^{\mathrm{c}, \mathrm{a}}$ & $43.54 \pm 0.36^{\mathrm{C}, \mathrm{a}}$ \\
\hline SHP & & $63.21 \pm 2.38^{A, b}$ & $61.15 \pm 0.62^{\mathrm{AB}, a}$ & $54.19 \pm 2.90^{\mathrm{A}, \mathrm{a}}$ & $39.84 \pm 0.20^{\mathrm{BC}, \mathrm{c}}$ & $17.68 \pm 1.56^{\mathrm{c}, \mathrm{b}}$ & $17.67 \pm 2.33^{\mathrm{c}, \mathrm{c}}$ \\
\hline HP & & $44.72 \pm 2.27^{A, C}$ & $41.74 \pm 1.83^{\mathrm{AB}, \mathrm{c}}$ & $31.82 \pm 0.32^{\mathrm{BC}, \mathrm{c}}$ & $26.85 \pm 0.86^{c, d}$ & $24.45 \pm 4.32^{\mathrm{c}, \mathrm{b}}$ & $22.90 \pm 3.75^{c, b c}$ \\
\hline Control & \multirow{4}{*}{$\begin{array}{c}\text { FW } \\
\text { (g/g solid) }\end{array}$} & $0.21 \pm 0.003^{\mathrm{A}, \mathrm{a}}$ & $0.16 \pm 0.002^{\mathrm{B}, \mathrm{b}}$ & $0.16 \pm 0.002^{\mathrm{BC}, \mathrm{c}}$ & $0.14 \pm 0.001^{\mathrm{cD}, \mathrm{b}}$ & $0.13 \pm 0.002^{\mathrm{D}, \mathrm{a}}$ & $0.08 \pm 0.01^{\mathrm{E}, \mathrm{b}}$ \\
\hline HNY & & $0.20 \pm 0.003^{\mathrm{A}, \mathrm{ab}}$ & $0.19 \pm 0.01^{\mathrm{A}, \mathrm{a}}$ & $0.12 \pm 0.002^{\mathrm{B}, \mathrm{a}}$ & $0.14 \pm 0.002^{\mathrm{c}, \mathrm{a}}$ & $0.14 \pm 0.004^{\mathrm{c}, \mathrm{a}}$ & $0.13 \pm 0.001^{\mathrm{c}, \mathrm{a}}$ \\
\hline SHP & & $0.19 \pm 0.01^{\mathrm{A}, \mathrm{b}}$ & $0.18 \pm 0.001^{A B, a}$ & $0.16 \pm 0.01^{\mathrm{B}, \mathrm{a}}$ & $0.12 \pm 0.001^{\mathrm{c}, \mathrm{c}}$ & $0.05 \pm 0.005^{\mathrm{D}, \mathrm{b}}$ & $0.05 \pm 0.01^{\mathrm{D}, \mathrm{c}}$ \\
\hline HP & & $0.13 \pm 0.01^{A, C}$ & $0.12 \pm 0.01^{A B, C}$ & $0.10 \pm 0.001^{\mathrm{BC}, \mathrm{c}}$ & $0.08 \pm 0.002^{c, d}$ & $0.07 \pm 0.01^{\mathrm{c}, \mathrm{b}}$ & $0.07 \pm 0.01^{c, b c}$ \\
\hline
\end{tabular}

*Values are means \pm SD of 3 determinations. A-D means with different letters in each row are significantly different. a-d means with different letters in each column are significantly different $(\mathrm{P}>0.05)$.

Table 10: Enthalpy $(\Delta \mathrm{h})$ and Freezable Water $(\mathrm{FW})$ Fraction of Bread Samples*

of control and HNY was closer to that of HP thereby giving bread of almost comparable or similar quality with a slower retro gradation rate.

\section{DSC analysis of control, HNY, SHP and HP}

The onset temperature (Table 9) of control bread decreased over the storage period though it varied significantly only between day 1 and day 12 while SHP showed significant difference after day 3. HNY and HP showed no significant change among the values. Day 1 showed significant difference only between control and HP while day 3 and 12 showed a significant difference between HNY and HP with HNY showing the lower value. On all other days there was no significant difference between the temperatures. The peak temperature decreased for all samples and significant difference was only seen between day 1 and day 12 for the control and between day 3 and day 6 for SHP. HNY and HP showed no significant change over the 12 days. Among the samples significant difference was seen on day 0 between control and HP, on day 3 between HNY and HP where HP had the lowest value. All other days showed no significant difference among the samples. The conclusion temperature, $\mathrm{T}_{e}$ showed a similar trend as $\mathrm{T}_{\mathrm{o}}$. the glass transition temperature $T_{g}$ (Table 9) showed significant difference between day 0 and day 12 for the control, between day 0 and day 9 for SHP but there was no difference during the storage period for HNY and HP. On day $0 \mathrm{HP}$ showed significant difference from the other samples. Day 3 showed no significant difference between control and SHP though they were significantly different from HNY and HP. Day 6 showed significant difference between HNY and HP while day 12 showed a significant difference between HNY against SHP and HP. In all the cases HP showed the lowest values.

The transition enthalpy $(\Delta \mathrm{H})$ (Table 10) on day 0 was highest for the control and differed significantly from SHP and HP where HP had the lowest transition enthalpy. All samples showed significant difference in transition enthalpy over the 12 days with the enthalpy decreasing and this decreased enthalpy was reflected the decreased amounts of Freezable Water (FW) fraction. The decrease in freezable water content (Table 10) suggests that more water was becoming immobilized and bound in the bread matrix with increasing time due to staling [33]. Roos [34] and Mohamed [26] reported that concentration of solutes such as sugars and salts caused a depression of the freezing temperature of the water phase which in this case could be seen by the decrease in FW which could cause an increase in the concentration of solutes thereby decreasing the ice-melting temperatures. The decrease in $\mathrm{FW}$ is thus contributed to moisture migration from the crumb to crust as well as its incorporation into the starch crystalline structure during staling as loss of crumb moisture only accounts for $38 \%$ of the reduction in FW [10].

\section{Conclusion}

A bread formulation using a $50 \%$ and $100 \%$ substitution of sugar with honey powder was developed. Physico-chemical and texture analysis of bread samples over a 12 day storage period have shown favorable and comparable characteristics of HP to the control bread. Loaf volume of HP was the highest in comparison with SHP and HNY as well as control. Staling rate was comparable between HP and control while SHP showed the highest staling rate. In terms of firmness HP was closer to the control on all days of storage while SHP and HNY showed extremely high values of firmness on all days. Overall, substitution of sucrose with $100 \%$ honey powder proved to be a viable option given the favorable characteristics it transferred to the bread as well as due to its characteristics being closest to the control.

\section{References}

1. Altamirano FR, Rosell CM (2011) Physico-chemical changes in breads from bake off technologies during storage. LWT-Food Sci Technol 44: 631-636.

2. Hathorn C, Biswas M, Gichuhi P, Bovell BA (2008) Comparison of chemical physical, micro-structural, and microbial properties of breads supplemented with sweetpotato flour and high-gluten dough enhancers. LWT-Food Sci Technol 41: 803-815.

3. Mondal A, Datta A (2008) Bread baking-a review. J Food Eng 86: 465-474

4. Ebaid GM, Faine LA, Diniz YS, Rodrigues HG, Galhardi CM, et al. (2006) Effects of digitonin on hyperglycaemia and dyslipidemia induced by highsucrose intake. Food Chem Toxicol 44: 293-299.

5. Vaclavik VA, Christian EW (2007) Essentials of food science. Springer, New York.

6. Scanlon M, Zghal M (2001) Bread properties and crumb structure. Food Res Int 34: 841-864.

7. Barcenas ME, Rosell CM (2005) Effect of HPMC addition on the microstructure, quality and aging of wheat bread. Food Hydrocolloids. 19: 1037-1043.

8. Stampfli L, Nersten B (1995) Emulsifiers in bread making. Food Chem 52: 353 360.

9. Hui YH, Corke H, De LI, Nip WK, Cross NA (2006) Bakery products: Science and technology. Blackwell Publishing, Ames, IA.

10. Ribotta PD, Le Bail A (2007) Thermo-physical assessment of bread during staling. LWT-Food Sci Technol 40: 879-884.

11. Mandala I, Karabela D, Kostaropoulos A (2007) Physical properties of breads containing hydrocolloids stored at low temperature. I. Effect of chilling. Food Hydrocolloids 21: 1397-1406

12. Patel B, Waniska R, Seetharaman K (2005) Impact of different baking processes on bread firmness and starch properties in breadcrumb. $\mathrm{J}$ Cereal Sci 42L: 173-184.

13. Bogdanov S (2011) Honey as nutrient and functional food: A review. Bee Product Science.

14. Mikulikova D, Masár Š, Kraic J (2008) Biodiversity of Legume Health-promoting Starch. Starch-Stärke 60: 426-432. 
Citation: Sathivel S, Ram AK, Espinoza L, King J, Cuetov R, et al. (2013) Application of Honey Powder in Bread and its Effect on Bread Characteristics. J Food Process Technol 4: 279. doi:10.4172/2157-7110.1000279

15. Shamai K, Bianco-Peled H, Shimoni E (2003) Polymorphism of resistant starch type III. Carbohyd Polym 54: 363-369.

16. Wang J, Rosell CM, Benedito de Barber C (2002) Effect of the addition of different fibres on wheat dough performance and bread quality. Food Chem 79: $221-226$.

17. Penfield MP, Campbell AM (1990) Experimental food science. Academic press.

18. Shogren R, Mohamed A, Carriere C (2003) Sensory analysis of whole wheat/ soy flour breads. J Food Sci 68: 2141-2145.

19. AOAC (1999) Official Methods of Analysis of the Association of Official Analytical Chemists. Vol II. Arlington, VA.

20. Le-Bail A, Boumali K, Jury V, Ben AF, Zuniga R (2009) Impact of the baking kinetics on staling rate and mechanical properties of bread crumb and degassed bread crumb. J Cereal Sci 50: 235-240.

21. Fu L, Tian JC, Sun CL, Li C (2008) RVA and farinograph properties study on blends of resistant starch and wheat flour. Agricultural Sciences in China 7: 812-822.

22. Ragaee S, Abdel-Aal ESM (2006) Pasting properties of starch and protein in selected cereals and quality of their food products. Food Chem 95: 9-18.

23. Zaidul I, Norulaini N, Omar A, Yamauchi H, Noda T (2007) RVA analysis of mixtures of wheat flour and potato, sweet potato, yam, and cassava starches. Carbohyd Polym 69: 784-791.

24. Borla OP, Motta EL, Saiz AI, Fritz R (2004) Quality parameters and baking performance of commercial gluten flours. LWT-Food Sci Technol. 37: 723-729.
25. Yi J, Kerr WL, Johnson JW (2009) Effects of waxy wheat flour and water on frozen dough and bread properties. J Food Sci 74: E278-284.

26. Sharadanant R, Khan K (2003) Effect of hydrophilic gums on the quality of frozen dough: II. Bread characteristics. Cereal Chem 80: 773-780.

27. Mohamed A, Xu J, Singh M (2010) Yeast leavened banana-bread: Formulation processing, colour and texture analysis. Food Chem 118: 620-626.

28. Gallagher E, Gormley T, Arendt E (2003) Crust and crumb characteristics of gluten free breads. J Food Eng. 56: 153-161.

29. Primo-Martin C, Van Nieuwenhuijzen N, Hamer R, Van VT (2007) Crystallinity changes in wheat starch during the bread-making process: starch crystallinity in the bread crust. J Cereal Sci 45: 219-226.

30. Korus J, Witczak M, Ziobro R, Juszczak L (2009) The impact of resistant starch on characteristics of gluten-free dough and bread. Food Hydrocolloids 23: 988995.

31. Mohamed A, Rayas D P, Xu J (2008) Hard Red Spring wheat/C-TRIM 20 bread Formulation, processing and texture analysis. Food Chem 107: 516-524.

32. Charoenthaikij P, Jangchud K, Jangchud A, Prinyawiwatkul W, No HK, et al. (2010) Physicochemical properties and consumer acceptance of wheatgerminated brown rice bread during storage time. J Food Sci 75: S333-339.

33. Baik MY, Chinachoti $P(2000)$ Moisture redistribution and phase transitions during bread staling. Cereal Chem 77: 484-488.

34. Roos YH (1995) Water and phase transitions. In: Phase transitions in foods, Academic Press, New York, NY 